151.

611.81

\title{
「インシュリン」ノ家鬼腦下垂體二 及ポス影響二就テ
}

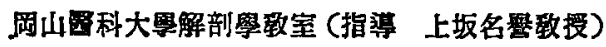

前田幹照

[昭和 7 年 6 月 24 日受稿]

Aus dem Anatomischen Institut der Med. Universität Okayama

(Leiter: Emeritus-Prof. Dr. K. Kösaka).

Über den Einfluss von Insulin auf die Hypophyse beini Kaninchen.

Von

Dr. Motouobu Maeda.

Eingegangen am 15. Jnni 1932.

Der Verfasser injizierte männlichen Kaninchen eine kleine Menge von Insulin (0.04 ce pro Kg Körpergewicht täglich einmal) durch 3-52 Tage hindurch, oder eine grosse Dose desselben Mittels (1.0 cc pro $\mathrm{Kg}$ Korpergewicht nach je 15 Minuten) 1-7 mal, und dann tötete die Tiere, um Veränderungen ilurer Hypophysen zu untersuchen, indem er sich der Cajalschen Uransilbermethode oder der Malloryschen und Eosinhaematoxylin-Färbung bediente. Daraus ergibt sich das Folgende:

Im Anfangsstadium des Experimentes (nach 3-7 Injektionen der kleinen Menge von Insulin oder nach 1-3 Injektionen seiner grossen Dose) treten zahlreiche acidophile Zellen im Vorderlappen der Hypophyse in die Erscheinung und ihr Golgischer Apparat springt in die Augen, wobei die Zellen mit dem acidophilen Sekret gefüllt und stark gespannt sind. Auch viele Blutgefässe im Vorderlappen sind mit demselben Sekret gepropft. Auf Grund dieses Befundes glaubt der Verfasser, dass das Sekret des Hypophysenvorderlappens mit Insulin eine ähnliche Wirkung hat, und eines von beiden das andere ersetzen kann. Seiner Meinung nach ist der genannte Befund der Hypophyse so zu deuten, dass durch Einfuhr des Insulin die Ausscheidung des Sekretes des Vorderlappens unnötig wird, was die Stagnation des Sekretes in den Zellen uud Blutgefässen zur Folge hat. 
Später aber werden die sekretgefüllện Zellen spärlich und anstatt ihrer treten kleine Zellen in die Erscheinung, wobei der Golgische Apparat der Zellen in den Hintergrund tritt. Diese Erscheinung beruht darauf, dass infolge der Funktionssistierung die Zellen des Vorderlappons allmählich der régressivạ Veränderung anheimfallen. (Kurze Inhaltsangabe.)

\begin{tabular}{|c|c|c|c|c|}
\hline & & 目 & 次 & \\
\hline 第 1 拿 & 緒 言 & & 第 5 章 & 結 諭 \\
\hline 第 2 章 & 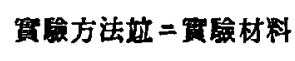 & & & 引用文能 \\
\hline 第 3 章 & 實䐘成績 & & & 捚圖說明 \\
\hline 第 4 章 & 精括及ビ考按 & & & \\
\hline
\end{tabular}

\section{第 1 章緒 要}

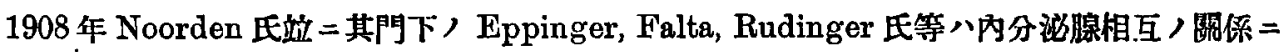

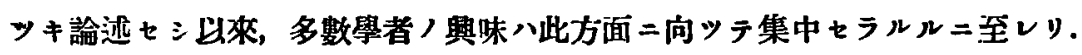

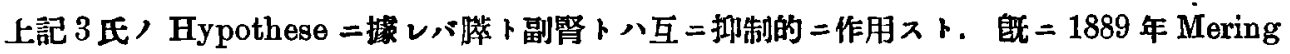

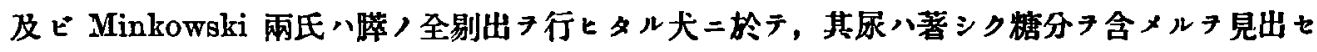
リ，其後 Macleod 氏八含水炭素新陳代謝，調節二八，膵ノ「ランゲルハンス」氏島/分泌波が

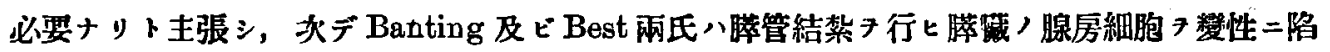
ラシタ，健存セル「ランゲルハンス」氏島ヨり其內分泌液，成分タル「インシュリン」フ創製スル ニ至レリ．此大發見ノ發表サルルヤ各國學者ハ競ツテ其照用》备方面二於テ試えタリ．從ツテ

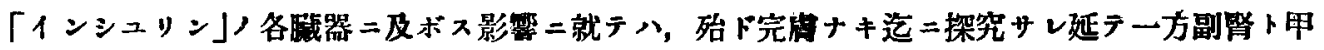

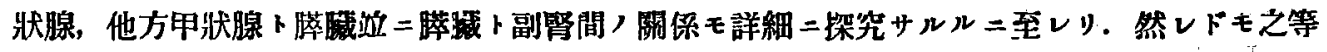

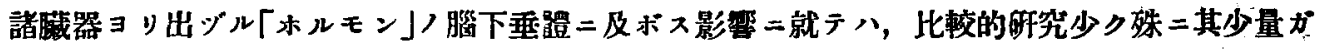

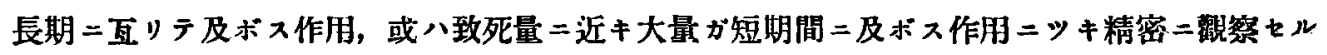
モノナキガ如シ。是レ余が本砄究二着手シタル所以ナリ。1922年「インシニリン」ノ發見サレシ

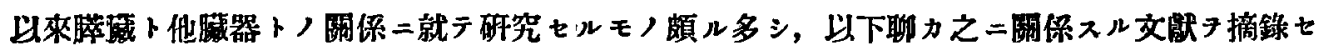
ントス. 其順序トシテ

（1）「インシュリン」ト到㛑物筫ト人相互關保二就テノ文噳

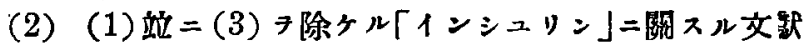

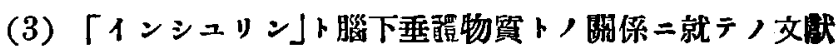

子記載センニ; 
(1).「インシュリン」ト副腎物質卜ノ相互關係二就テ

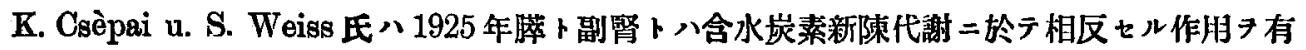
スルモ血粒量トノ關係习調查セント欲シ，人二於テ「インシュリン」站ニ「アドレナリン」ヨ用 ヒテ探案セリ、氏等ハ「インシュリン」八血糖量ノ減少セル場合二於テハ,「アドレナリン」作

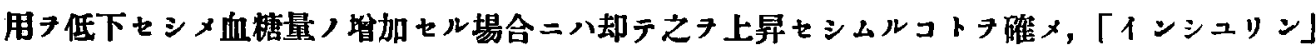
ト「アトレナリン」ト八相拮抗スルガ如キモソ八血糖量ノ變化二因スルモノニシテ Hormon 自 體ノ直接ノ作用ニアラズトセり． M. Tschebolssaroff u. Z. Malkins 氏(1925)等八犬二於テ 「インシュリン」ト「アドレナリン」トノ作用ヨ檢セシニ「インシュリン」八副腎ノ「アドナり ン」分论二對シ刺戟的二作用スルモノナルコトフ確メテ日ク, Nach unserer Ansicht ist es notwendig in dieser Richtung eine Korrektion in dem Schema von Eppinger, Falta und Rudinger vorzunehmen ト.A. Gottschalk氏 氏 (1925)ハ「インシニリン」フ蛙二投與スルトキ

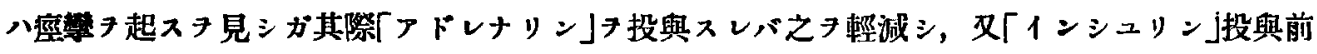

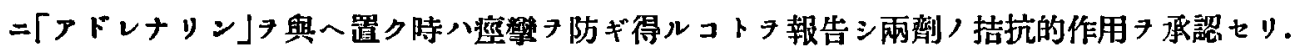

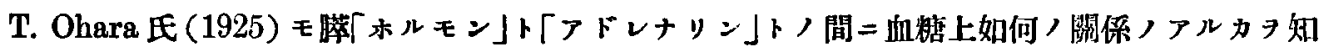

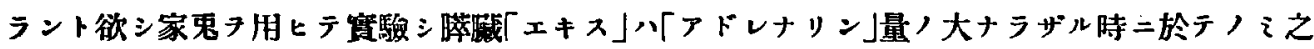

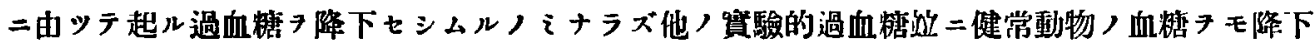

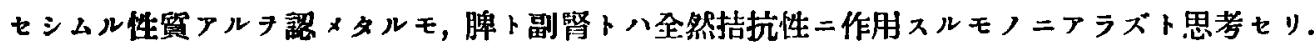

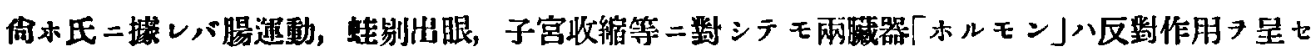
ズト。

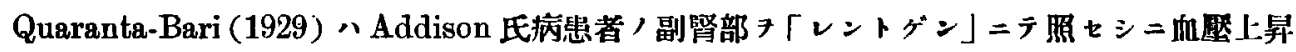

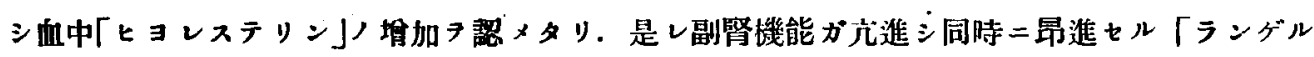

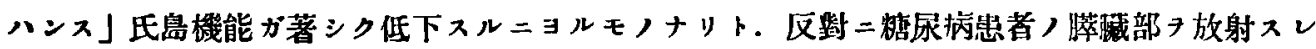
バ Glykamie 及ビ Glykosurie ハ輕減シ著シク「ランゲルハンス」氏島，機能ガ充進セルタ認

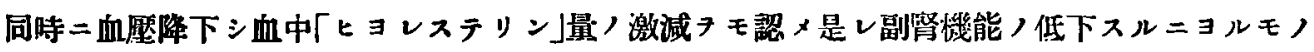

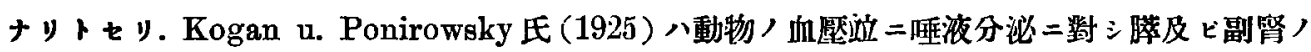

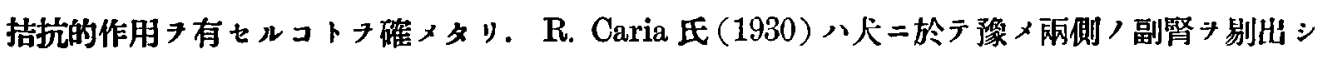

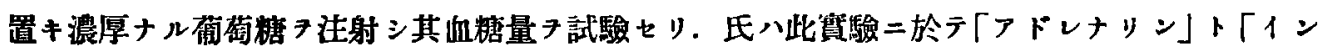
シュリン」トノ間ニハ少クトモ血糖調節二關シ捛抗的作用ノ存スル事タ報告七り. 若林氏 (1925) 八家鬼二用七テ「インシュリン」的ニ「アドレナリン」ノ血榙二及ボス影䁩习检シ此 2 者八互二拮 抗的二作用スルコトタ確メタリ，桶口隆藏，田近稔兩氏八家兔二就キ「アドレナリン」及ビ「イ

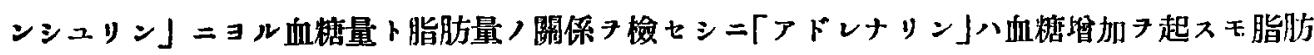

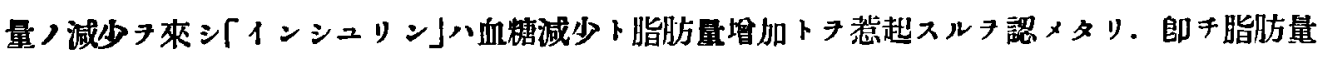
二於テミ血糖量二於テモ「インシュリン」ト「アドレナリン」ト八拮抗的二作用スルモノトセリ。 
野坂綱定氏 (1925) 八比較的大ナル「ラッテ」ニ於テ「インシュリン」注射ニヨリ未が豦玅性中毒 应フ起サザル時期二於テ既二副腎內「アドレナリン」含有量八著シク減少スルタ見タリ「アドレ

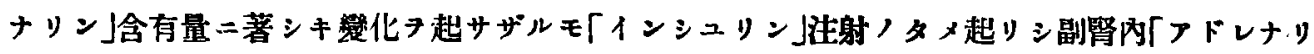
ン」含有量ノ減少八之二由ッテ抑制セラル故ニ「インシュリン」及ヒ「「ドレナリン」ハ副腎二對

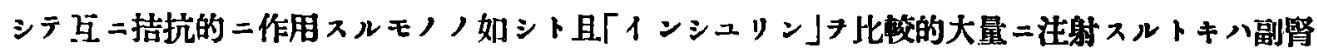

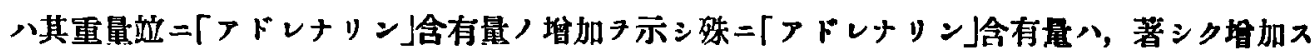

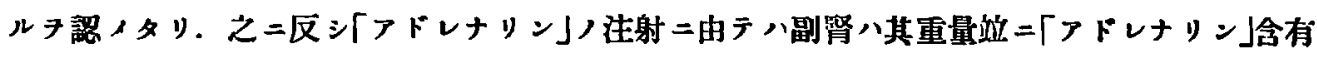
量二著シキ堆加ヨ示サズト。

靑木主計氏 (1928)，八牝犬 7 用ヒテ其等素新棵代 謝 上ニ於テ「インシュリン」及ピ「ドレナリン」ガ 如何，舉䋆

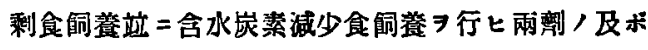

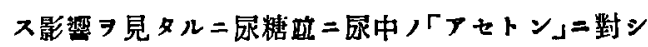

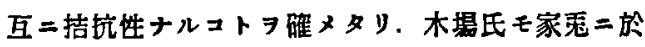
テ雨劑ガ互二拮抗的二作用スルコトタ確メタリ．清 成要平氏 (1999) 、雄性白鼠二於テー方「インシンリ

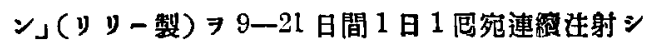

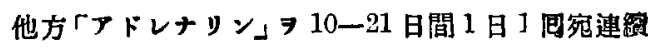

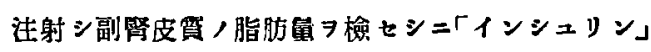
ニテ八副腎皮質，脂肪殊二中性脂肪，減少 7 來シ， 「ナドレナリン」ニテハ其堵加引認メタリ．宮村三郎 氏 (1929) 八冬眠「ガ、」テアドレナリン」或ハ「イン

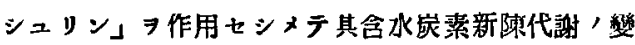

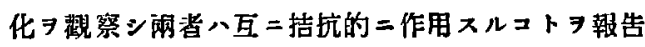
セり.田桑冥男氏 (1930) 八雄性，比較的大ナ几家冤 二就テ兩劑ガ血夜「グルタチォーン」ノ上二如何／影

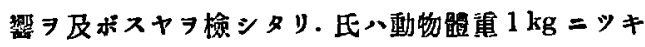
「リリー」製「インシュリン」1單位宛ヨ皮下二迬射セ シ $=1$ 封 30 分㷋二於テ其堿少，倾间 7 見タリ. 观 ニ「アドレナリン」1000倍派 $0.5 \mathrm{ccm}$ ヨ皮下=注射七

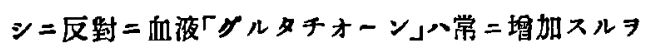

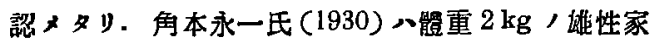

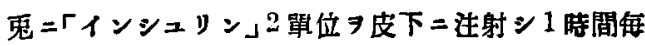
二血液 7 㭘セシニ赤血球網瀻維状物實八減少或八其
傾向ヨ示シ之二反シ「アドレナリン」 $1 \mathrm{ccm} \exists$ 注射 スレパ 30 分， 1 時間， 2 時間，3時間後二於テ同藏 維物，增加，增大／傾向 (1930) 八體重 $1 \mathrm{~kg}$ kgキ「ナドレナリン」1000倍 液 $0.1 \mathrm{ccm}$ 宛或ハ「インシュリン」1單位宛 7 開腹後

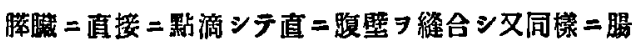
管ニモ點滴セシニ「テドレナリン」，㛫合 $=$ ハ生理

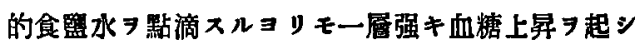

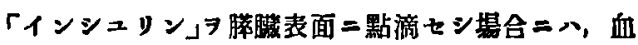
精一時上昇ス几モ食監水 ニシテ次デ直二降下シ再ビ稍々上昇スルョ見タリ.

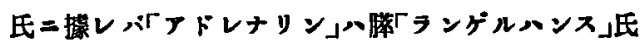
島，作用 $\Rightarrow$ 低下セシメ「インシュリン」ハ之ヨ刺戟シ テ其機能ヨ旺盛ナシシムルモノナリト，村尾䐒雄氏

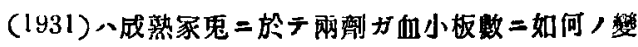

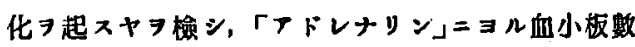
，增加ハ「インシュリン」ニヨリテ著シク抑制サル ルガ如シト云へリ。侗ホ氏ハ「インンニリン」1日

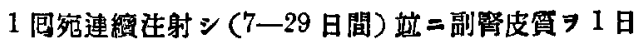

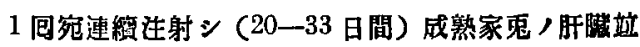

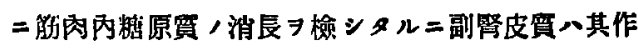
用、「インシュリン」二比シ弱シト踓モ, 兩者心共

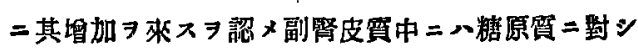
テ「インシニリン」ト同㧼ニ作用スル物貿厂リトセ y. 


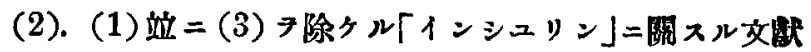

E. Bissinger, E. J. Lesser u. K. Zipf 氏八蛙二於 テ「インシュリン」注射ニョリテ解肉及ビ胿虂中，糖 原䨘ノ減少スル 認× Marrian u. Stuub 兩氏そ之=

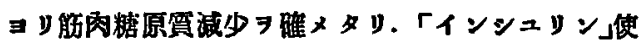

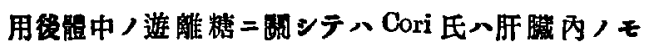

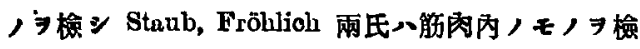
セy. 又 Weber, Köchig 氏等八正常犬二於テ「イン

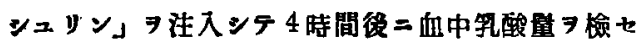

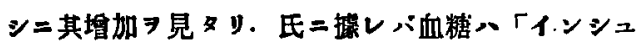

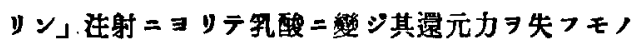
ナリト. T. Okumurn (1926) 氏八家兔 / 新陳代謝 $=$ 就キ甲狀㙞ト「インシュリン」トノ相互關䋆ヨ檢シ， 甲犾腺ニヨリテ甾淮セジラレタル新陳代謝ハ「ィ ンシンソン」ニョリテ明カニ抑制サルルニ至ル. コ

(3).「イシシュリン」ト腦下垂體卜關係二就テノ文塥

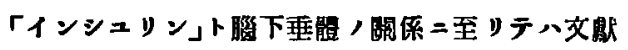

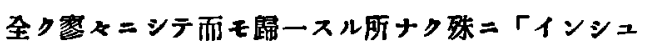
リン」ノタメ二起ル下垂體構适, 就中其細胸內微細

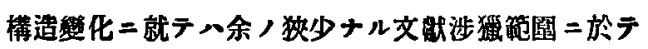
八文暗甚ダ僅ナルガ如シ. 今「インシュリン」ト腦下

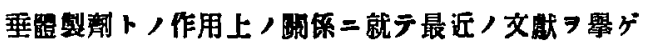
ע= G. Jonchimoglu u. A. Metz 氏 (1924) 八家产， 血糖这 =海㩧子宮二颜テ研究シ「インシンリン」ト下 垂路製新ト互二拮抗性二作用スルモノナルコトラ

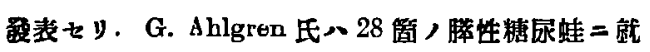
テ研究シタル二觔肉組織呼吸，上ニ於テ「ピッイト ソン」ト「ィンシニリン」トハ互二促進性=作用スル モノナルコトョ知得タリト. Elizabeth C. Enves 孃へ(1926)鼠ニ「インシニリン」ヨ反覆注射シタル

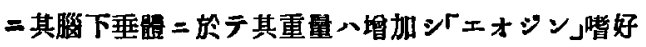

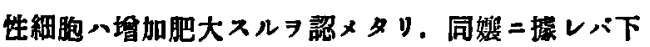
垂體ハ「ィンシュリン」’血糖降下作用习抑制スト。

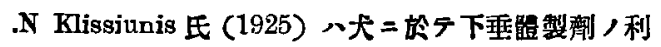

ヘ「ンシュリン」ト甲㭊腺トノ拮抗的作用二起因ス ルナラント.J. Burn and H. Mrrks 氏心(1925) 甲

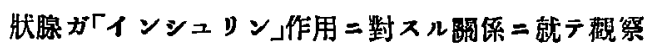
シテ日ク，甲狀踩剔出ハ「テドレナリン」/血糖增進 作用 $\rightarrow$ 減ジインシュリン」血糖低下作用 7 買淮セシ

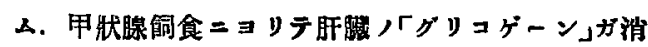
失シタル時ハ,「マドレナリン」血糖增進作用八減 退シ「インシュリン」/血糖低下作用八增進スト。 K. Csèpai u. Z. Ernst 氏 (1927)等ハ「バセドウ」氏 病患者二於テ「インシュリン」生射

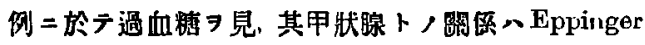
氏等, 称一ル如ク拮抗性,モノニアラズシテ互二促 進的ノモノナリトセり. 


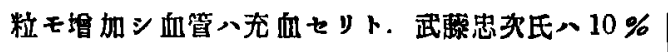
「インシュリン」液 0.25-5oc ヨ每日「ラッテ」!皮下

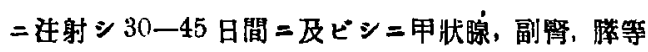

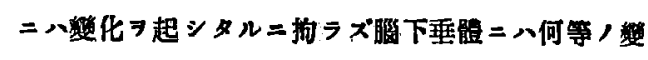
化モ恋メザリシト。

\section{第 2 章賽驗方法站二赛験材料}

1) 「インシニリン」注射八其注射部伦这二方法二

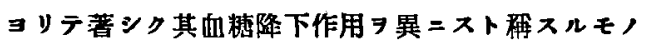

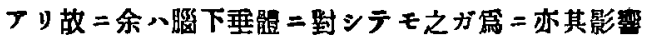
ニ差アランカニ留意シ注射ハ總テ皮下トナシ留部左 右间侧二交互二之 7 行七\$y.

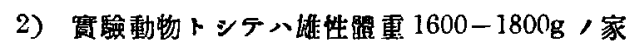
鬼ヨ用ヒ之ョ 2 種二分チタリ。

3）少量注射長期ノモイト，大量注射短期ノモ， トセり.

4)「インシュリン」ハ米國「リリー」會社製习用七 長期少量ノモ八體重 $1 \mathrm{~kg}=ッ キ 0.4$ 單位宛每日午 後 5 時注射セり，而シテ注射 3 包，7回，15回，30 回，52回後 24 時間习桱テ各《空氣栓塞ニテ之き殺

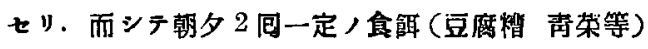
與一タע.

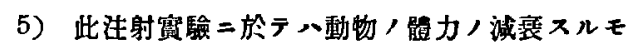
ノ多カリシモ能食後二注射ヨ行へバ其度少カリキ。

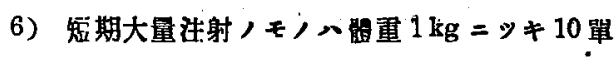
位宛 15 分間隔 7 以下 过射其第 1 八只 1 回，注射 後 15 分二テ殺シ第 2 ， 15 分間淂=テ注射

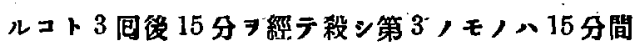

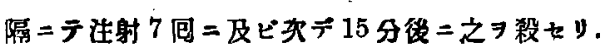

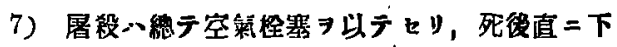

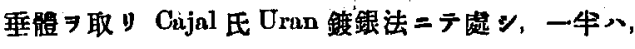
師

Uranfixierung

10 St.

1.5\% Silbernitrutlösung 浸清 36 St.

Heidrochinonlōsung 浸漬 24 St.

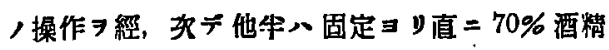
习經テ Mallory 氏染色法，即千

$\begin{array}{ll}\text { 1\% S. Fuchsin 液 } & 2 \text { 分 } \\ \text { Phosphormolybañnlösung } & 5 \text { 分 } \\ \text { Mnllorylösung } & 1 \text { 分 }\end{array}$

或、Hämatoxylin-Eosin 染色法 7 行七検セ $y$.

\section{第 3 章實 驗 成 績}

\section{A)「インシュリン」少量長期注射}

（1 日 1 回䯣重 $1 \mathrm{~kg}=シ キ 0.4$ 單位宛）尹行ヒタル家兔腦下垂體所見

1）腦下垂體前葉 Golgi 氏裝置所見

a）第 1 實驗 注射 3 厄後ノモ，

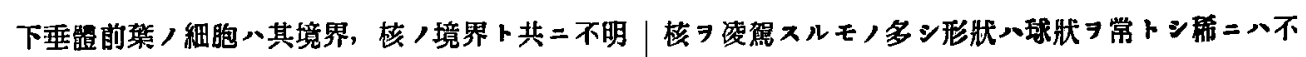

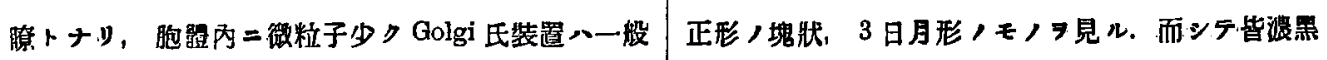

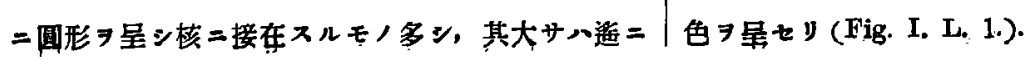


Fig. I. I. 1.

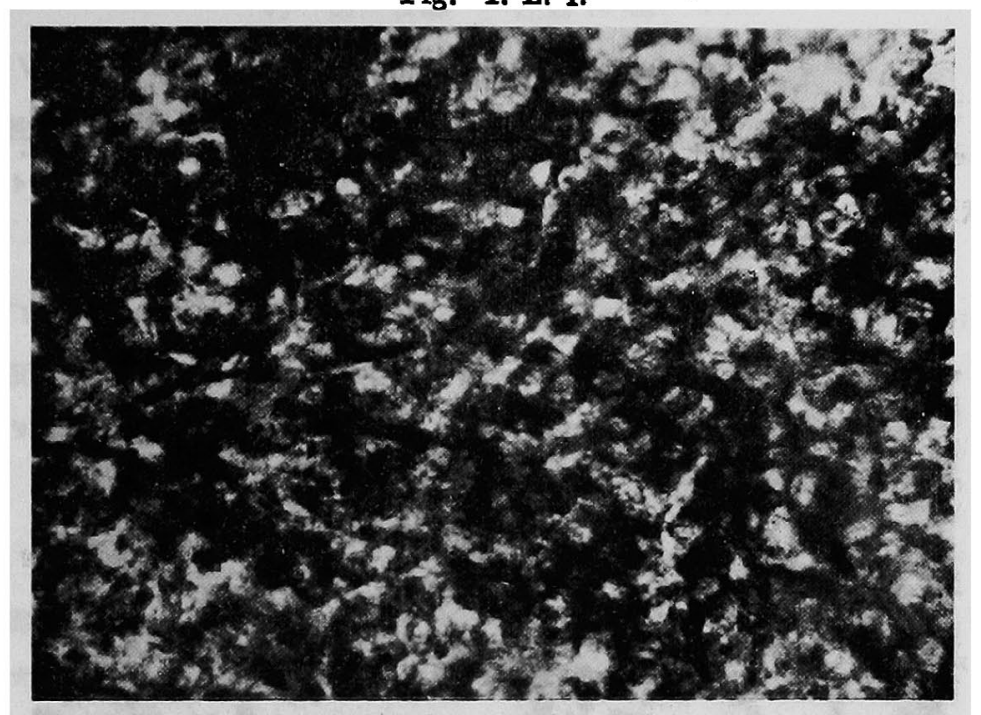

b）第 2 䨘驗注射 7 回ノモノ

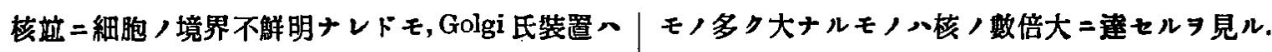

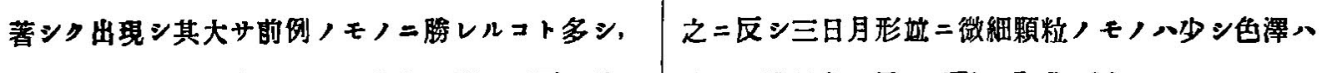
形狀、前例，如ク球形ナラズ大小不同ノ不正塊狀，著シク漶黑色习呈 ス (Fig. I. L. 2.).

Fig. I. L. 2.

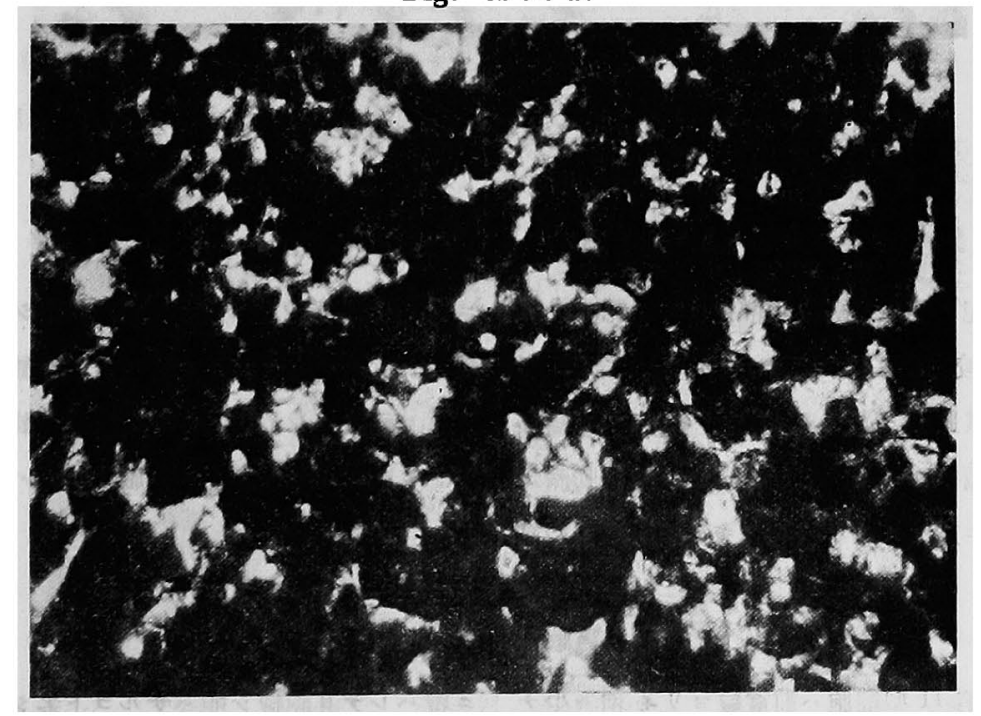

c）第 3 實驗 注射 15 回ノモノ

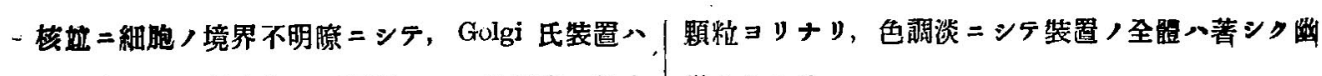
著シクホトナリ形狀多りハ球形ニシテ其形菜へ粗大|微トナソリ: 
d）第 4 䁈驗 注射 30 间ノモノ的=

第 5 賽驗 注射 52 回ノモノ

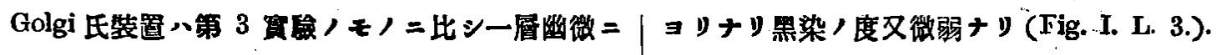
シテ從シテ形肰ヌ小ナリ. 其形素ハまトシテ微䊀子

Fig. I. I. 3.

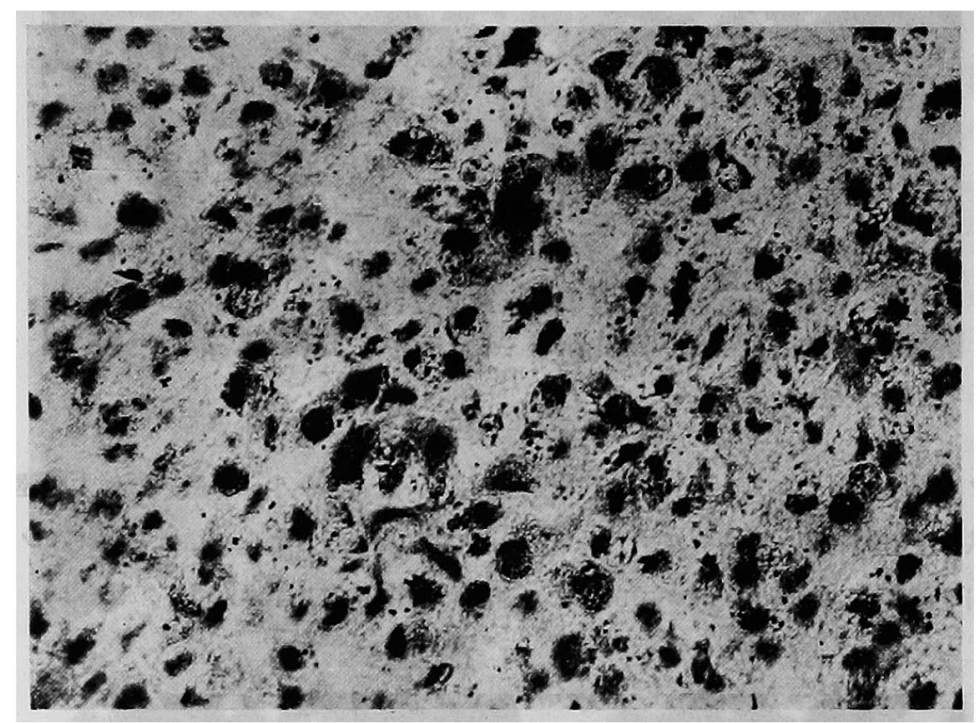

2） Mallory 氏染色法二ヨル所見

\section{a) 第 1 賽驗 注射 3 间ノモノ}

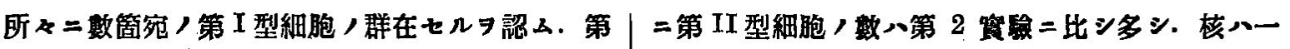
II 型細胞、比較的少ク最モ多キハ第 $\mathrm{V}$ 及ビ第 VI 型

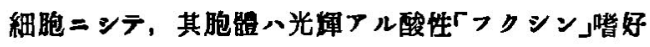

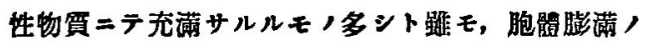

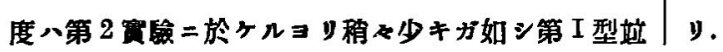

\section{b）第 2 残驗 注射 7 间ノモ，}

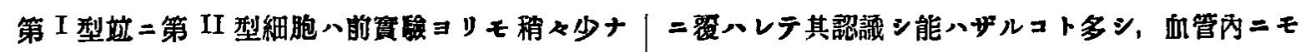
3 ，第 V 型、第 VI 型細胞八第 I 及ビ第 II 型細胞二

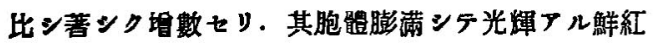
色，好酸性「フクシン」物質二テ充填セラレ櫒ハタメ

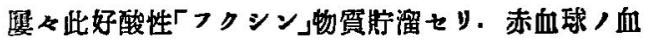
管外二脫出セルョ見ルコトアリ．一股三細胞ノ機能 旺盛ナルカノ如キ肰习示セリ。 
c）第 3 實駲注射 15 问ノモ，

第 $\mathrm{V}$ 及ビ第 VI 型細胞ハ著シク減挽シ，且胞體中 二上記ノ光蜔性鲜紅物賀 $ヨ$ 含ムコト少ナク核八能》 証諲シ得ルコト多シ，加之血管內二モ同物留

d）第 4 筫驗 注射 30 问ノモノ

第 $\mathrm{V}$ 及ビ第 VI 型細胞ヘ著シク減政シ，鮮紅色，

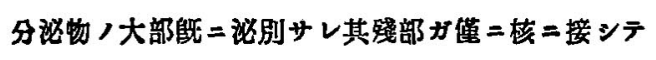

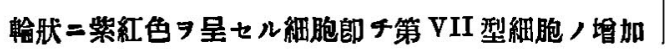

○）第 5 筫驗 注射 52 间/モノ

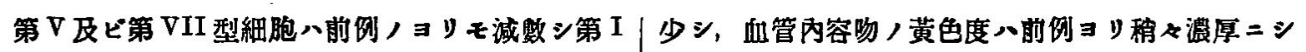
型, 第 II 型細胞一熄數七リ. 第 $\mathrm{V}$ 型細胞, 胞體八前

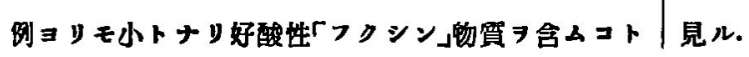

B）「インシュリン」大量短期泩射

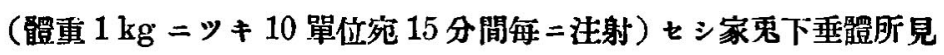

1）腦下垂體前葉，Golgi 氏裝置ノ所見

a) 第 1 實媛 注射 1 回ノモノ

荄，境界鮮明ナレドモ，細胞，境ハ不明膫ナリ| (Fig. I. K. 1.).

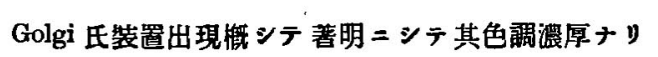

Fig. I. K. 1.

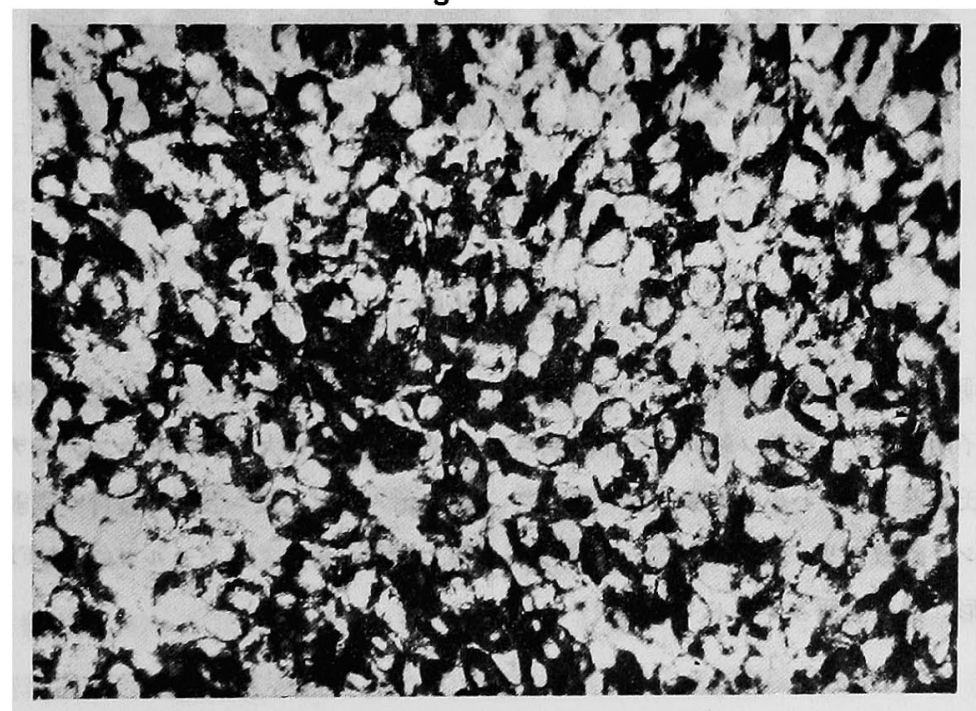




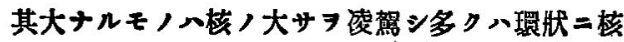

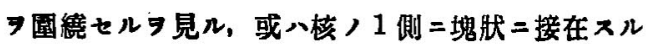
そノナリ三日月形ヨ旺シ又八微細䊀子ョリナレルモ

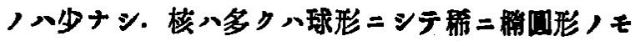
ノョ見ル.

\section{b）第 2 實媛 注射 3 回ノモノ}

核站二細胞ノ境界概シテ不鮮明ナレドモ Golgi 氏

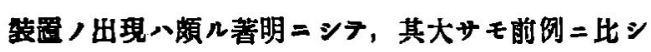
著大ナリ多ク八柆二接在セル大塊肰物トナリ現レ或

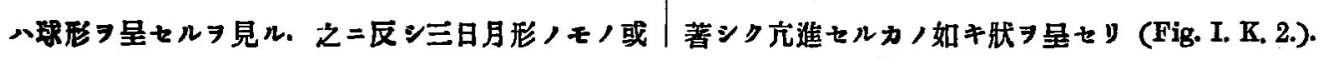

八微椟子ヨリナレルモノハ極 $\times テ$ 稀ナリ，其大ナル

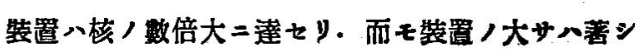

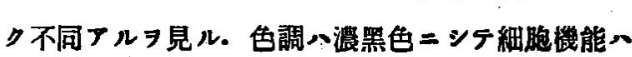

Fig. I. K. 2.

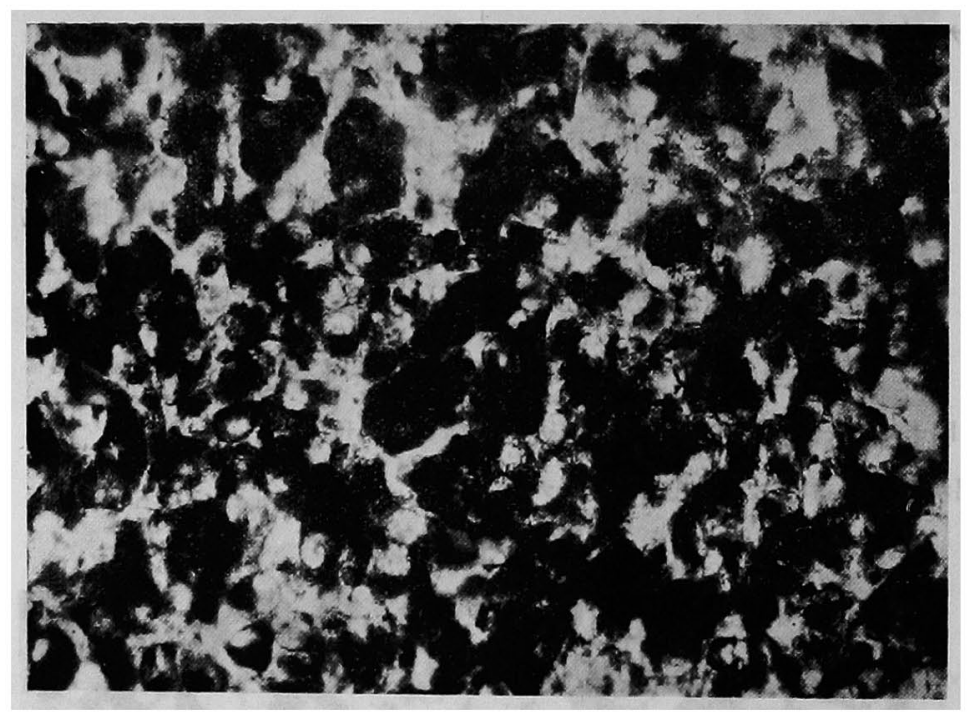

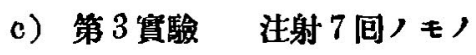

芝ノ境界ノ明瞕ナルモノ前侧ヨリモ稍く多キモ尚 东其大多數心不明腹ナリ. 細胞，境界モ的不鮮明二 シテ，Golgi 氏装㯰ハ多クハ小ニシテ黑色＼cjkstart度墽ク 其出顯ノ度著シク幽微ナリ，装置ノ形胛八不整形， 三日月形，球形，塊状等㮔※ナレド塊狀ノモノ 
Fig. I. K. 3.

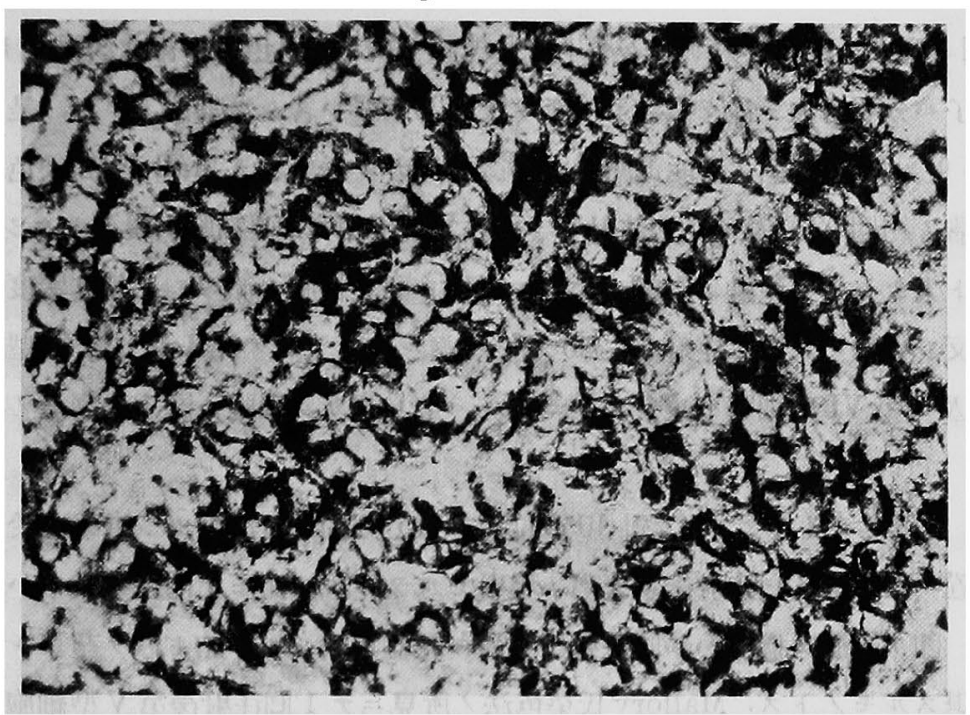

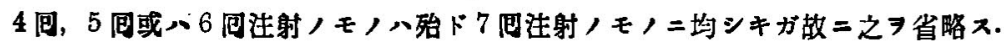

2) Mallory 氏染色法 $=コ$ ル所見

a) 第 1 實䐘注射 1 回ノモノ

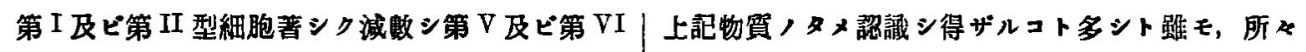

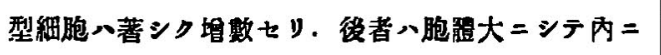
好酸性「フクシン」物貿 7 充满シ緊張，極點二達七ル カ如キモノ多シ，此種細胞一裐所二密在又、散在

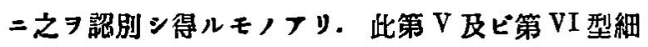
胞，出現，度八少皇注射 3 四，場合 $コ$ モ一展顯著 ナリ. レドモ殊二血管，周園二沿ヒ存在セルョ見ル。核八

\section{b）第 2 瞔駿注射 3 回ノモノ}

第 I 及ビ第 II 型細胞八前测(大量 1 回注射) ヨリ モ著シク堽數セリ．之二反シ第 $\mathrm{V}$ 型及ビ第 VI 型細

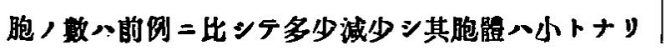

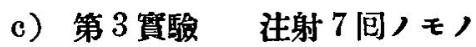

第 V 型及ビ第 VI 型縕胞ハ著シク弱ク染色シ其胞

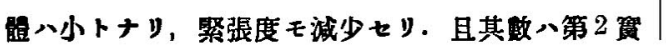
䲆ニ比スレハー一首著シク減少シ，之二代りテ第I 及 ビ第II 型細胞增數セリ。

\section{第 4 章 總括及ビ考按}

以上成縝子總括スルニ少量師千顝重 $1 \mathrm{~kg}$ 二就キ「インシュリン」0.4 單位宛每日注射セシモ

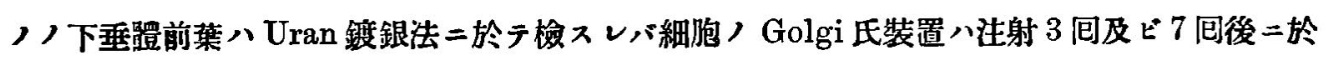


テ大トナリ，塊狀或ハ球形ノモノ多ク且泿黑色フ是シ萻明二出現スレドモ注射ノ四數 15 间, 30

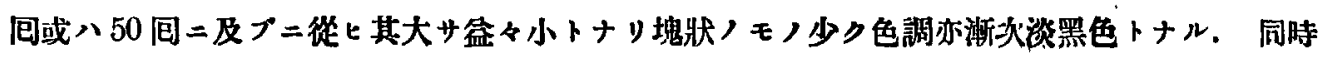

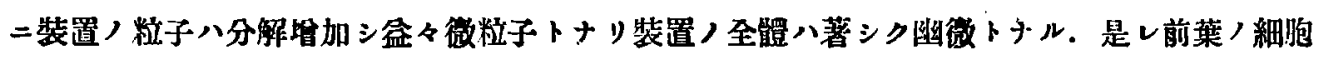

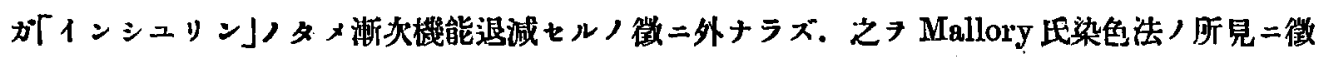

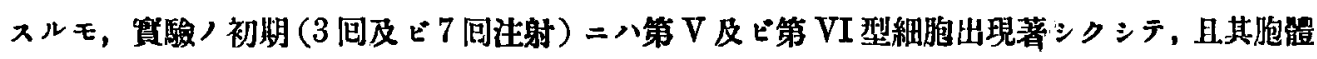

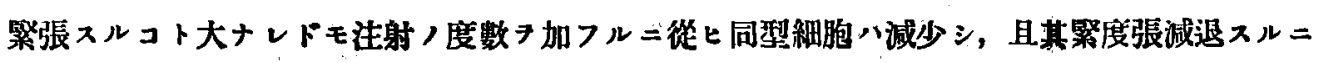
至ル. 之二反シ實驗，末期（注射 $30-50$ 回二及心゙ルモノ）二八第 I 及ビ第 II 型細胞多數二現 出シ，第 V及ビ第 VI型細胞ハ減少スル二至ル，是レ明カ二細胞，機能，害退，徵卜見做スへ キモノナリ。

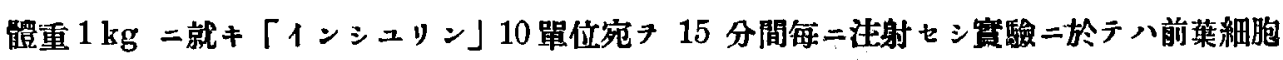
Golgi 氏装置八殊二第 3 回注射後二著明二現出セルチ見ル。而モ 7 回注射後二八却テ幽微卜ナ ルモノトス. 即チ細胞ノ機能ハ 3 包注射後二最モ旺盛トナレルが如キ狀キ呈スルモ7回注射後 二八却テ衰退スルモ，トス. Mallory氏染色法ノ所見二テ 1 回注射後第 V 型細胞最モ多數二出 現シ且其胞能，緊張度最大ニシテ 3 回注射後ニハ其度少シク減ズルガ如キモ墫ホ 7 间往射後， 場合ヨリモ造二第 $\mathrm{V}$ 型細胞ノ多數ニシテ且大ナルタ認ムルモノナリ.

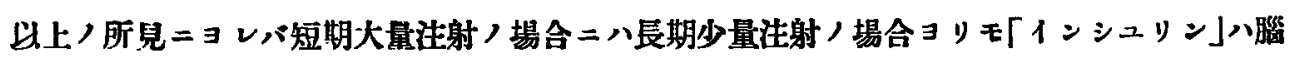

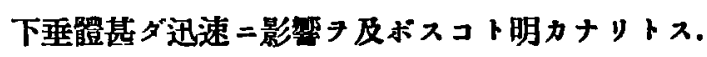

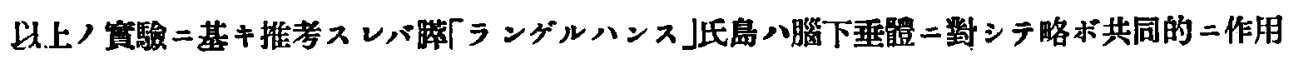
スルモノニシテ「インシュリン」少量注射ノ場合二於テモ亦大量注射/場合二於テモ賽䁩ノ初

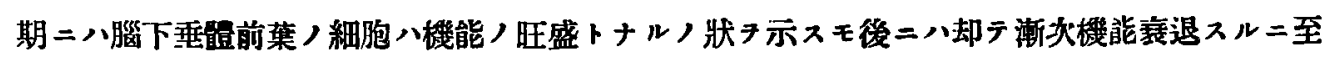

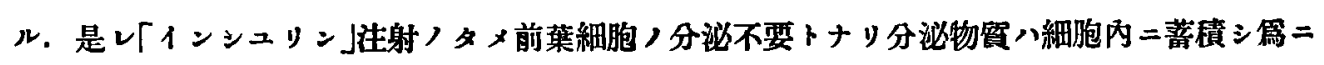
細胞八機能立進七シカノ如キ狀フ星スレドモ, 久シク分汹不要トナリ細胞/作用停止スレバ細

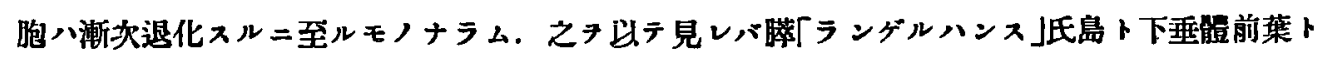
八互二共同的二作用スルモノナルコト疑タ容レザルガ如シ.

Joachimoglu u. Metz, Lawrence, Hewlett, Serebrijski u. Vollmer 站=Klissiunis 等,

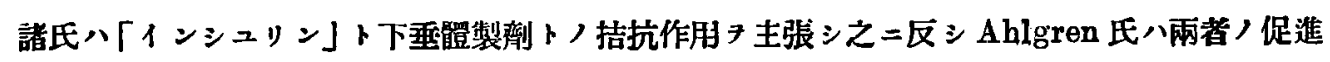
的作用习高唱七ルモ余八意見二據レハ雨者八殆ド同一作用ヨ有スルモノニシテ，「インシュリ ン」フ反題注射スル時八下垂體前葉二於テ最初ハ井倉氏ノ所見ノ如ク「エオシン」乃至酸性「フ

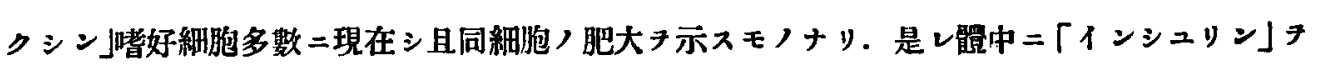

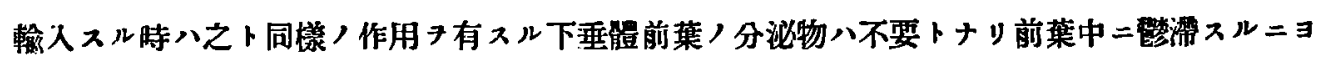

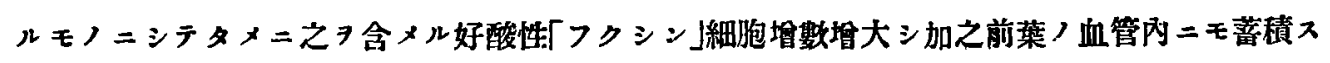

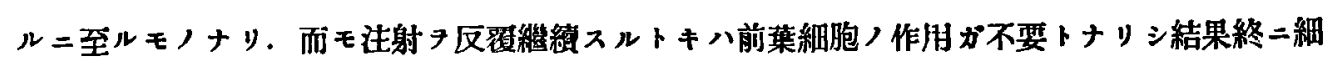
胞ノ退化テ來シ好酸性「フクシン」細胞ハ娍數シ第 I及ビ第 II 型ノ細胞ノ坦加テ見ルニ至ルキ 


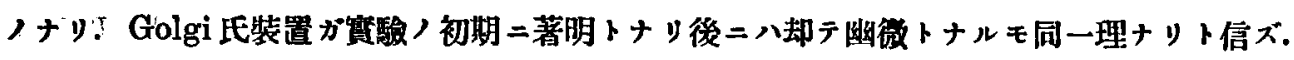
即キ余ハAhlgren 氏ノ誈二賛セザルフ得ズ.

\section{第 5 章結論}

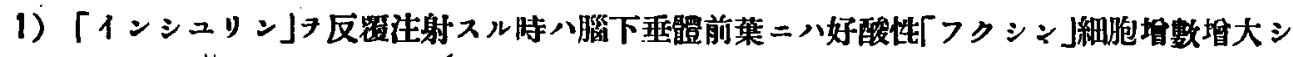
其 Golgi 氏装置モ著明二發有スルォ見ルト雖モ，實驗長時間二因ル時ハ，同細胞／作用不要卜 ナリタメ二細泡㕷二其 Golgi 氏裝置八退行性變性ヌ示ス二至ル。

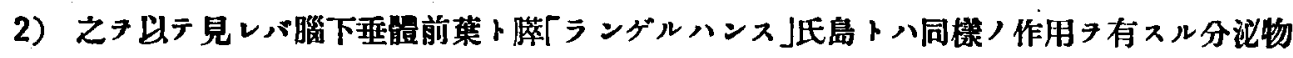
フ產出スルガ如シ.

3）「インシュリン」ハ之キ少量宛久シキ二互りテ反镜注射スルョリモ，其大量フ短期間二反 腊注射スル時ハ下垂體二速二變化ヲ起スモノナリ。

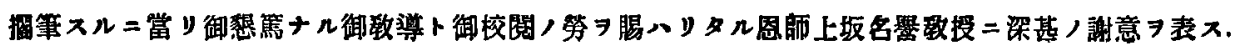

\section{文 獻}

1) 木㘿，中外贯事新報，第 1069 號，大正 13 年. 2) Eppinger, Falta u. Rudinger, Zeitsch. f. klin. Med. Bd. 66, S. 1, 1908. 3) Boden, Determan w. Wankell, Klin. Woch. 5 Jg. Nr. 38, 1925. 4) $K$. Csippai u. S. Weiss, Wien. Arch. f. inner. Med. Bd. X, 1925, 5) 松尾勝婎, 日本內分䎵學

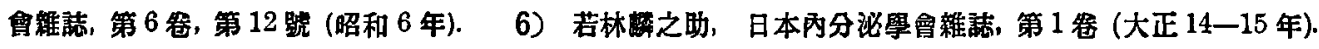

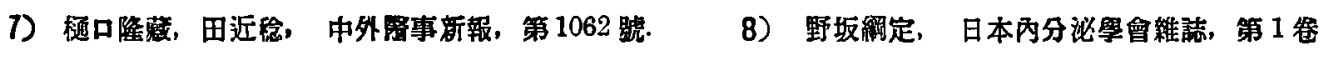
(大正 14-15 年). 9） Ohara, The Tohoku Journ. of Exp. Med. Vol. VI, No. 344, 1925.10 ） C.

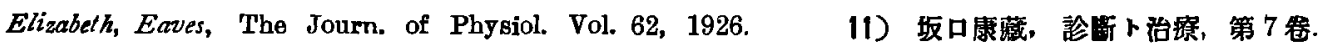

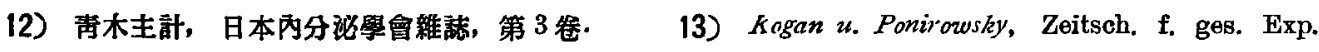
Med. Bd. 4T, 1925. 14) A. Gottschalk, Bioch. Zeitsoh. Bd. 160, $1925 . \quad$ 15) Verrom, Oent. f. allg. Path. u. puth, Annt. Bd. 31，Nr. 20,，1921. 16）上野 貞，日本內分泌學曾䧴志，第 4 替.

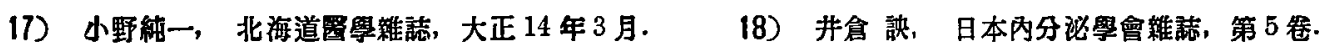
19) M. Tscheboksaroff u. Z. Malkin, Zeitsch. f. d. ges. exp. Med. Bd. 47, H. 5-6, 1925.20 ) 馬

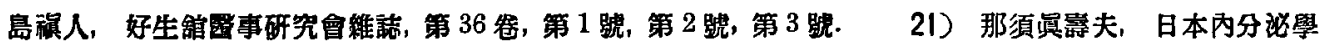

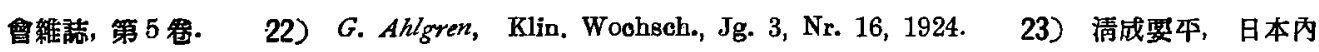

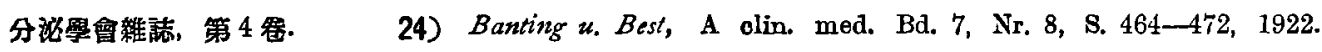
25) G. Joachimoglu u. A. Metz, Deutsch. med. Wochsch., Jg. 50, Nr. 51, 1924. 26) G. Pighini,

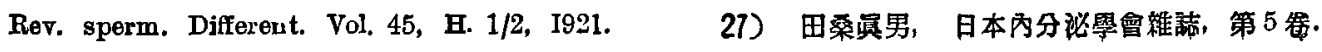


28) n. K7issizunis, Bioch. Zeitsoh. Bd. 160, H. 1/3, $1925 . \quad$ 29) Kratus, Oentralb. f. allg. Pnth. u.

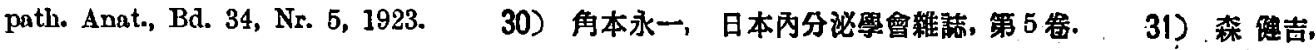
日本內分议學曾維誌, 第 2 危. 32） R. D. Lawrence, R. F. L. Hewlett, Brit. med. Journ., Nr. 3361,

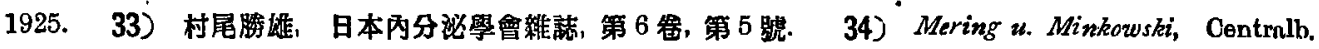
f. inn. Med. S. 393, 1889. 35) Schrwab, Centrulb. f. nllg. Path. u. path. Anat., Bd. 33, Nr. 68,

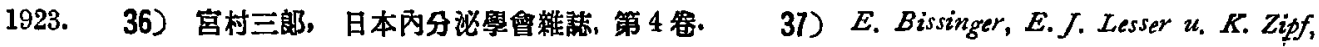

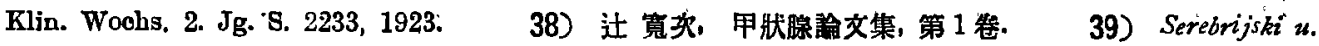

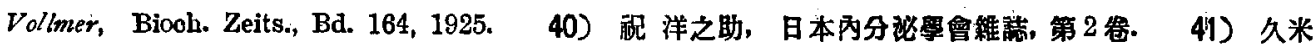

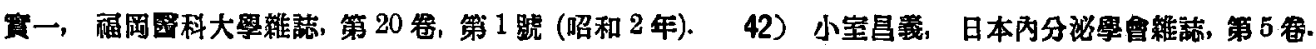

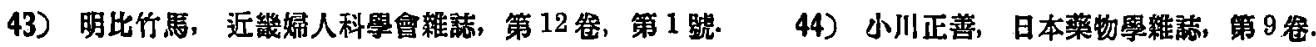
45）田坂静哉，中濢盛興 日本內分泌學會雜誌、第 6 卷. 46）小屋迫鹤陫, 日本內分泌學會雜誌, 第 6 卷. 47) T. Okumura, Biooh. Zeitsohr. Bd. 176, H. 4/6, 1926. 48) J. Bum and H. Mairks, Journ. of Physiol., Vol. 60, p. 131-141, 1925. 49) K. Csèpai u. Z. Ernst, Münoh. med. Woohschr. Nr. 41，S. 1757，1927. 50）美間 武，日本內分泌學曾雜誌，第 5 卷. 51) 有馬英二，日本內科學

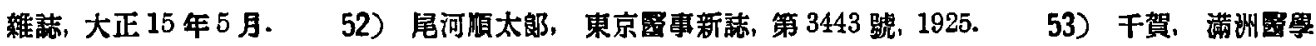
新誌, 大正 14 年, 15 年. 54）劉陸一，日本內科學會雜誌，第 12 卷. 55）樋口隆藏。田近念

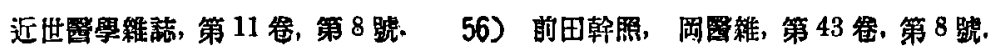

\section{揮圖說 明}

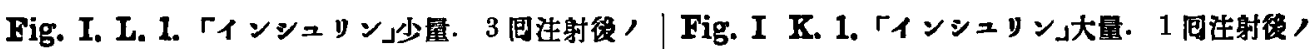
家兔瑫下垂咀前藮. 「ゴルギー」氏裝置 Cujalsche Cransilbermethode. Vergr. Zeiss. Obj. 40. Okl. 7. Krmernlänge $40 \mathrm{~cm}$.

Fig. I. L. 2. 「インシスンン少量. 7 国这射後

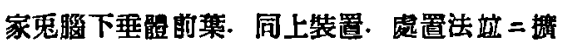
大周上

Fig. I. L. 3.「インシニンン少量. 52 尼过射後

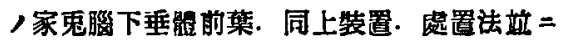
摭大同上。

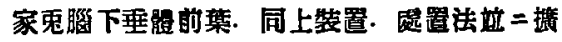
大同上

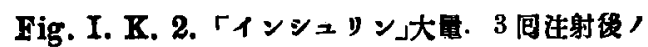

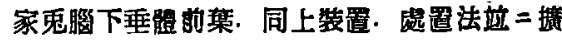
大同上

Fig. I. K. 3.「インシンリン」大黾. 7 回注射啳，

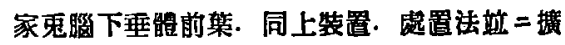
大同上 